cells are absolutely free from them. The experiments incidentally have a bearing upon the action taking place on the sensitised photographic plate.

\section{THE ROYAL INSTITUTE OF PUBLIC HEALTH.}

A SPECIAI summer course of lectures are being delivered at the Royal Institute of Public Health from May 11th to July 6th inclusive. On the first-named date Mr. T. W. Aldwincle, F.R.I.B.A., dealt with the subject of the Construction of Public Health Laboratories, and on May 18th and 25th respectively Dr. R. Tanner Hewlett will take for his subject the Etiology of Epidemic Diarrhœa and Professor Thomas Oliver Diseases of the Lungs caused by Dusty Trades ; on June 1st Colonel David Bruce, R.A.M.C., will lecture on Sleeping Sickness; on June 8th Dr. George Newman will discuss the question of Milk-borne Diseases; on June 15th Mr. W. J. Dibdin, F.I.C., will deal with the Bacterial Treatment of Sewage; on June 2Znd Major William Boog Leishman, R.A.M.C., will lecture on the subject of Kála Ázar and Tropical Cachexia and their Relation to the New Parasites; on June 29th Professor Sheridan Delépine will discuss Anthrax in Great Britain; and on July 6th Mr. Alexander Macmorran, K.C., will deal with Some Legal Difficulties in the Administration of the Public Health Statutes. The lecture hour is 5 P.M.

Dr. Henry Head will deliver a special address at the Royal Medical and Chirurgical Society on the Afferent Nerves under a New Aspect on Tuesday, May 23rd, at 8.30 P.M. The conclusions expressed are drawn from investigations carried out in conjunction with Dr. W. H. R. Rivers, Fellow of St. John's College, Cambridge, and Mr. James Sherren, assistant surgeon to the London Hospital.

THE annual dinner of the Indian Medical Service will $b_{e}$ held at the New Gaiety Restaurant, Strand, London, W.C., on Thursday, June 8th, at 7.45 o'clock, when the chair will be occupied by Surgeon-General James Cleghorn, C.S.I. Officers intending to be present should communicate as soon as possible with the honorary secretary, Lieutenant Colonel P. J. Freyer, 46, Harley-street, London, W.

THE annual dinner of the Epidemiological Society of London will be held at the Grand Hotel, Trafalgar-square, London, W.C., on Friday, June 30th, at 7.15 P.M., when the chair will be taken by the President, Dr. B. A. Whitelegge, C.B., H.M. Chief Inspector of Factories. Application for tickets may be made to the honorary secretaries, Dr. H. Timbrell Bulstrode and Dr. W. H. Hamer.

THE King bas sanctioned the following promotion in, and appointments to, the Order of the Hospital of St. John of Jerusalem in England-viz., Knights of Grace: Charles Cotton, M.R.O.S. Eng., F.R.C.P. Edin. (from Honorary Associate); Lieutenant-Colonel Sir James Richardson Andrew Clark, Bart., C.B., R.A.M.C.; and George Lane Mullins, M.A., M.D. Dub.

A TELEGRAM from the Governor of Hong-Kong received at the Colonial Office on May 15th states that for the week ending May 13th there were 17 cases of plague and 12 deaths from the disease.

A NET home for men in connexion with the Metropolitan Convalescent Institution has been built at Little Common, Bexhill-on-Sea, and will be opened on Saturday next, May 27th.

\section{A NOTE UPON THE NEILSON SYSTEM OF SEWAGE PURIFICATION.

\author{
By H. LaING Gordon, M.D. Edin.
}

CoNSIDERABLE interest has been aroused in Italy amongst sanitarians by the application of a new system of sewage purification to cesspools. The usual method of sewage disposal in Italian towns is by deposit of the house sewage into a cesspool directly connected with the house. These cesspools are emptied with more or less regularity, but, as all travellers on the continent know, their presence leads to the fouling of the atmosphere. The new system for which Mr. Montgomerie Neilson of Florence is responsible is said to be free from the objections pertaining to the old system. It is claimed that no odours whatever are given off by it, that the cesspool never requires to be emptied, and that the effluent may be syphoned away perfectly clear and drained into the ordinary surface drain. Indeed, the inventor makes the statement that the effuent is the purest effluent produced by any system of sewage purification. A further important statement maintains that disease germs are completely destroyed within the cesspool.

It will be agreed that if these statements can be wholly proved a very important advance has been made. I have had the advantage of seeing the new system in action and of obtaining a partial explanation of the mode of action from the inventor who has patented his system throughout the world.

The following is Mr. Neilson's own statement regarding his system: "By means of this discovery it is possible to convert a cesspool full of sewage into clear water in a sufficiently short time to allow of the clear water running off whilst the fresh sewage takes its place. A particular species of specially cultivated micro-organism is introduced into the cesspool. These speedily bring about the natural process of decomposition by which the sewage is resolved into gases and clear water. The cesspools are aero-anaerobic. This means that the sewage is at one part of the cesspool in contact with air whilst at another part it is deprived of air. These different parts of the cesspool are inhabited by different colonies of micro-organisms, each doing its own particular duty, devouring any casual disease germs, splitting up gases and preventing their noxious exhalations, and finally allowing the altered sewage to run off as clear water. The cesspool merely consists of a tank provided with (1) a sewage inlet; (2) an outlet for the altered sewage ; (3) a ventilator; and (4) a passage through a partition built in the cesspool to separate the micro-organisms into two divisions. There is besides a separate chamber with an automatic flushing syphon. The cesspool does not need to be emptied. It empties itself automatically. No smell whatever is given off. Not only is the cost of emptying saved but the risk of conveying disease is avoided because the anaerobic bacteria, or disease germs, which flourish in the absence of oxygen, become a prey to their ravenous enemies, who in comfortable surroundings and with plenty of food and air transform the solids into gas and water with magic rapidity. As an extreme precaution the transformed liquid can be treated automatically in a patented, antiseptic well which destroys effectually every living organism, leaving a sterilised effluent. In country places where there are no rain drains the liquid can be run off or be thrown on the land as manure. The cesspool is of indefinite durability and once it is installed requires no attention and involves no working expense."

The municipality of Florence has investigated Mr. Neilson's system and has granted him permission to apply it wherever desired throughout the city and to discharge the transformed liquid into the street drains. The following is the certificate of the analyses of the effluent made by the municipality on the strength of which Mr. Neilson obtained his permission.

Sample No. 1.-Cesspool in Lung'Arno Guicciardini No. 11. Physical characters : clear, inodorous water. Reaction markedly alkaline. Fixed

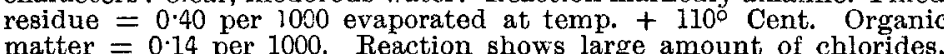
matter $=0.14$ per 1000 . Reaction

Sample No. 2-Cesspool at Parsonage of Cestello. Physical Sample No. 2.-Cesspool at Parsonage of Cestello. Physical characters : clear, inodorous water. Reaction markedly alkaline. Fixed residue $=0.53$ per 1000 evaporated at temp. + 110 Cent. Organic matter $=0.07$ per 1000 . Reaction shows large amount of chlorides
traces of sulphates and nitrates. 
I add a copy of another analysis made by the Royal Technical Institute of Florence :-

Physical characters: The liquir is colourless, "slightly opaline on account of finely divid 3 d solid matter held in suspensiun and the large number of micro-organisms Odour very faint, almost imperceptible. number of micro-organisms gravity at $15^{\circ}=1002$. Reaction, slightly alkaline Substances held in solution: iron, lime, magnesium, potassium, sodium, silicic acid, sulphuric acid, hydrochloric acid, phosphoric acid, ammonia, and traces of nitrogenous organic matter. Tests for nitrates, nitrites, and sulphuretted hydrogen gave negative results. A test to determine the quantities gave the following results: Matter in suspension $=0.067$ per litre; residue at $100^{\circ}=3.126$ per litre; ash $=0.3448$ per litre; chloride 0.1603 per litre; organic nitrogen $=0.302$ per litre; nitrogen as ammonia
$=0.11$ per litre $=0.11$ per litre; total nitrogen $=0.412$ per litre. From the results of in Via Aretina, N. 6, may without risk b3 discharged into the city in viains.

And a third analysis made by Professor Ubaldo Mussi of Florence :

Specific gravity, 1002; reaction, slightly alkaline; colour, palo amber yellow ; odour, almost imperceptible and not disagreeable, after a short exposure to the air it disappears entirely; appearance, opalescent; ammonia, present in small quantity ; nitrites, none; nitrates, substances, none; urea, none ; lime, traces; chlorides, traces ; sulsubstances, none; urea, none; lime, traces; chlorides, traces; sul phates, traces; phosphates, none. In the sediment obtained by centrifugal process several paramecium coli were found, some non characteristic, and therefore indefinable, detritus. The opalescence of the liquid is due to the paramecium; on standing a short time in becomes quite clear-i.e., on the death of the paramecium whose life in
the liquid is of very short duration. In conclusion, the component parts of the fæces, including the urine, contained in the cesspool in Lung'Arno Guicciardini N. 11, subjected to treatment by the Montgomerie Neilson system, are totally decomposed and transformed, and the liquid produced is, in its chemical composition. very different from sewage and presents rather the physical characters of inferior drinking water, hence its discharge $i_{i}$, to the sewers is perfectly harml $l_{\text {ss }}$

The practical result of the investigation on the part of the municipality has been the reception of a large number of orders for installations from municipalities and private persons throughout Italy and applications for particulars from other countries. Mr. Neilson informs me that the system is now being investigated by the Pasteur Institute of Paris. It may be seen in full working order in many houses in Florence and there is no doubt that the statement that evil odours are abolished and that the effluent is colourless as well as odourless is absolutely true $I$ have inspected the effluent on a good many occasions. I have found it slightly milky at first owing to the living infusorians present but it becomes perfectly clear after standing a few days when the infusorians have perished. It has a faint smell of truffles at first. One installation has been in action now for three years and is said to have required no attention whatever and to be absolutely satisfactory.

The most important point to elucidate is-What influences bring about these results and how do they work? As I have said already it is difficult to obtain precise information on this subject. I have, however, been shown under the microscope by Mr. Neilson specimens taken from the cesspools and, as far as I can make out, the work is done by one variety of anaerobic bacterium, which he cultivates specially, and by several varieties of infusorians, which are, of course, aerobic. I have not seen the anaerobic bacterium but $\mathrm{Mr}$. Neilson informs me that it works at the bottom of the cesspool upon solid excrement, breaking it up and rising to the upper regions of the cesspool with the disintegrated particles. Here these bacteria form food for some of the infusorians which in their eager endeavours to devour the bacteria further break up the particles of solid matter. Under a magnifying power of 200 diameters I have had two brief glimpses at the infusorians and observed at least five varieties. They all seem to eat voraciously and are all freeswimming and marvellously active. Their movements vary, some darting rapidly, some vibrating, some twisting, and some rotating. The larger varieties are distinctly ciliated and my impression is that they all belong either to the ciliata or flagellata. A very definite mouth is present in the larger varieties. Mr. Neilson states that one variety eats the solid matter, two varieties destroy the anaerobic life, another one feeds on the matter which is in process of liquefaction, and a fifth eats incessantly apparently whatever it comes in contact with, including bacteria, cocci, \&c., and takes a large share in the clearing of the liquid. I gather from the inventor also that these infusorians split up the gases and that the ultimate gases formed are carbonic acid gas and marsh gas " and others which have a smell like truffles." $\mathrm{He}$ is very emphatic in stating that these animalcula can live only when the gases are allowed to escape. He informs me that the lowest temperature at which the system has hitherto been found to work successfully is $4^{\circ} \mathrm{C}$ and that the highest hitherto tried is $38^{\circ} \mathrm{C}$. It will be understord that a system with the pretensions of this one will find its greatest application in countries where cesspools are used for sewage disposal, but Mr. Neilson states that he is fully prepared to apply it on a large scale to the water drainage of cities and asserts further that his system will displace others on account of its efficiency, cheapness, comparative rapidity, and automatic action. It will be observed that he places no reliance whatever upon the bacteria which are ordinarily found in sewage; he says that he has no use for them. This and the use of infusorians characterise the system and mark it off from other systems of bacterial sewage purification I can obtain no absolute proof of the destruction of disease germs under the process.

Mr. Neilson himself confesses that he is an amateur at the subject but has devoted six years entirely to its investigation. I understand that the inventor's attention was first directed to the subject by observations upon the life found in pools into which the house drainage of his villa near Siena ran. One cannot fail to be impressed by Mr. Neilson's enthusiasm for his subject and by the successful results which are evident on an inspection of one of his cesspools in working order. The naked-eye superiority of Mr. Neilson's effluent placed side by side with specimens from Sutton and Exeter is striking. Even if all the statements made do not prove on further investigation to be entirely correct, nevertheless every dweller in the cesspool-riddled cities of the continent will have reason to be grateful if the system is more generally applied. Indeed, in Florence already many of us are thankful for the removal of offensive odours from spots which we frequent or from the neighbourhood of our dwellings, and it is a further satisfaction to know that the municipality has approached Mr. Neilson with a view to the application of his method to that eyesore of the city, the system of urinals.

Florence.

\section{ROYAL MEDICAL AND CHIRURGICAL SOCIETY.}

\section{The Centenary Programme.}

THE following and final programme, celebrating the Centenary, has now been arranged by the council of the society with the help of the Centenary Committee. The information has been published in our columns already in detail but our readers may wish to see the complete arrargements as a whole.

Monday, May 22nd, "Centenary Day."-At 5 o'clock P.M. the President will receive the Honorary Fellows and Fellows at the Society's House, 20, Hanover-square, W. Light refreshments will be provided from 4.30 P.M. onwards.

At 5.15 the President will deliver a short congratulatory address. After the address he will admit the new Honorary Fellows and present them with their diplomas.

The Centenary Banquet will be held at the Hotel Cecil at 8 P.M., but Fellows and guests are requested to be seated in their places punctually at 7.45 in order to be ready to receive His Royal Highness the Prince of Wales.

At 7.45 the Prince of Wales will sign the roll of the society, be admitted an Honorary Fellow, and receive his diploma.

Tuesday, May 23rd.-At 8.30 P.M. Dr. Henry Head, F.R.S. (Marshall Hall prizeman), will deliver a special address on the Afferent Nerves under a New Aspect. The conclusions expressed in the address will be drawn from investigations carried out in conjunction with Dr. W. H. R. Rivers and Mr. James Sherren. After the address there will be an informal reception by the President and council.

Wednesday, May 24th.- There will be a conversazione in the Natural History Museum, Oromwell-road. A reception will be held by Sir R. Douglas Powell, P.R.C.P. Lond., the President of the Society, and Lady Powell from 9.30 P.M. to 10.30 P.M.

An arrangement has been made with the District Railway Company by which on this evening the subway connecting the South Kensington station with the grounds of the museum will be open for the use of guests.

A small, but it is hoped an interesting, exhibition will be arranged in the society's rooms for the inspection of Fellows and others from Monday, May 22nd, to Thursday, May 25th inclusive, between the hours of $11 \mathrm{~A} . \mathrm{M}$. and $6.30 \mathrm{P} . \mathrm{M}$. each day. 